\title{
Analyzing the Problems of Independent College Teaching Quality and its Influencing Factors
}

\author{
Dong-Ping Wang, Xiao-Hui Song, Shu-Zhen Hao, Jun-e Zhou \\ Bin Yang, Yi-Nuo Liu \\ Department of Science \& Technology, Agricultural University of Hebei, Baoding 071001, China \\ Mechanical \& Electrical Engineering College, Agricultural University of Hebei, Baoding \\ 071001, China \\ qceftgh@126.com
}

Keywords: Independent college, Teaching management, Influencing factors.

\begin{abstract}
Teaching quality is a key of independent college talent training. This paper summaries the content based on the connotation of independent college teaching quality and teaching characteristics, analyzing the existing problems in independent college teaching quality from the aspects of students, teachers and the classroom teaching effects etc, indicating that the main factors affecting independent college teaching quality are the featureless goal of training talents, unreasonable professional setting, unsound teaching management system, unstable teachers and imperfect monitoring system of teaching quality.
\end{abstract}

\section{Introduction}

Independent College, a product of development and reform of higher education, is to conform to the popular trend of higher education model and the emergence of higher education, social organizations or individuals outside of universities and colleges collaborate with national institutions to implement education bachelor degree or above, the use of non-state finances of the funds held in order to implement undergraduate education based colleges and universities [1]. According to statistics, Independent Colleges currently has been confirmed by the Ministry of Education, which assumed the third undergraduate training mission, independent college plays an important role in undergraduate education in our country [2]. Therefore, exploring the effective management model of the independent college and improving the quality of personnel training has very important significance.

\section{The Connotation of the Independent College Teaching Quality}

The word meaning of quality is rich.Different subjects, different areas have different meaning. In the field of higher education, quality of teaching is the core structure of the overall structure of school education's quality.It is a growing, evolving systems.people and their effects on teaching and learning activities reflect the values [3]. As the "quality" is a relative concept, the quality of higher education is constantly changing in many ways. Different teaching objectives, different quality standards have different quality of teaching. In general, the quality of teaching can be divided into two levels: First, the basic quality requirements of higher education that college education must in accordance with the educational purpose and training objectives, through the dissemination of knowledge and the exploration of the truth.cultivate the personnel who have a innovative spirit and practical skills; Second, specific personnel training standards.It refers to the different levels of higher education defined quality standards for specific training objectives [4].The standard of the independent college's teaching thequality achieved is an independent institute that meet the government, society, employers, parents and students' clear requirement for teaching activities, and with the development of productivity and evolving with the times and technology, so that the people have the ability to satisfy their self need. Therefore, people trained by independent college should not only have personnel training standards of university, but also the with good character, excellent 
professional skills, excellent social competitiveness, a high degree of social responsibility, good human qualities and ability to innovate.

\section{The Teaching Characteristics of Independent College}

\section{The Particularity of the Independent College Students}

From the school students' foundation, the Independent College Admissions belong to undergraduate batches, under normal circumstances, independent college admissions is after regular undergraduate enrollment. The admission average score is lower than the average undergraduate score 30 points to 100 points. We can say that among the entire population of students in colleges and universities, the weak of the basics of the independent college students is an indisputable fact. From the point of view of learning initiative, compared with ordinary undergraduate schools, a few students in dependent colleges have a strong self-motivated and self-control,. And there is less difference between the achievement of ordinary undergraduate students and the independent college students .However, the majority of independent college students' goals are not clear, learning lack of motivation, interest in learning is not strong, poor self-control, learning methods shall not be treated. From the quality of students, the independent college students have active thinking, and strong expression. Compared with ordinary undergraduate schools, independent college students' communicative ability and practical ability is better, expertise of our students, and willing to participate in school sports activities, experimental curriculum, internships and they are more interested in science and technology innovation.

\section{The Instability of Independent School Teachers}

According to the requirements of the Ministry of Education, China's independent colleges should have no less than 100 people, who have more than one year's duration of employment, relatively stable full-time faculty, and full-time teachers should have a ratio of not less than $30 \%$ of the senior title. However, compared with the ordinary graduate school, teacher in independent colleges have broader sources. Under normal circumstances, the main source of most of the independent Faculty has the following three categories : part of the parent school teachers selected to assume the independent college teaching tasks, and hire retired teachers from other colleges and universities or other enterprises, professional and technical staff as part-time teachers. Based on the consideration of establishment of full time teachers in dependent college, improving their own faculty structure considerations, introducing the high-level, highly educated professionals. Overall, teachers constitute of independent college undergraduate are more complicated than ordinary schools, pluralistic, is not conducive to the communication and exchange between teachers, between teachers and students, the teaching work lacks cohesion.

\section{Independent College Teaching Management is more complex}

Due to the diversity and speciality of the students and teachers in the independent college, makes independent college teaching management more complex than other colleges and universities, and also more difficult to train than ordinary undergraduate school. On the one hand, independent colleges need to address talents. The contradiction between personnel training objectives and student-based conflicts. The reason is that according to the Ministry of Education's personnel training requirements of the independent college, training goal is to develop an independent college filled with innovative spirit and the practical skills of application-oriented talents, .In considerderation of the students in independent college with poor school infrastructure, independent college need to give more consideration to the characteristics of students in developing talent training program, teaching content, teaching methods, and take various measures to implement individualized. On the other hand, independent colleges need to address some of the problems caused by the diversity of teachers. The factor contributing this is that the lifeblood of the school and the classroom teacher is the first responsible person, for the education which play a key role in independent college teaching. However, there are few full-time teachers in the independent college,So teachers instability, mobility makes the teaching organization more difficult. 


\section{There is a Problem of Teaching Quality of Independent Colleges}

\section{Lack of Motivation of Student Learning}

The survey found that independent college students have active thinking, most students were active in sports and other activities in practice. However, the independent school students in learning showing the scene of polarization, about a quarter of the students have a high enthusiasm for learning and have academic excellence, the majority of students lack of motivation. Mainly in the following aspects: First, the students' learning objectives are not clear, they lack of enthusiasm and motivation to learn, some students believe the book knowledge in school and social knowledge can not converge,. They think classroom learning is boring; the second is serious truancy, students poor attendance, class late, absent for class, stepping into the classroom when the bell ring such prominent phenomenon, this phenomenon is worse at senior college students, senior's students' average attendance is only $40 \%-50 \%$; Third, student labor does not contribute, although some students attend class on time, but they didn't learn carefully in class, they read the books which has nothing to do with the look of books, magazines, or surf on the Internet, chat, and even some students in the classroom are still play the self-timer, eat.

\section{The Teachers are not Enthusiastic}

Independent colleges' teachers have diversity, there are fewer full-time teachers, and the teaching level is uneaven between teachers, also there are less communication between teachers and students some teachers are not enthusiastic about teaching. The reasons are: First, most of the independent college's teachers have heavy task of teaching faculty, which make teachers lose interest in work, some teachers don't prepare lessons seriously and make no vivid slides, which affects class effect; Second, in general independent colleges operate under the laws of the market, unstable students, teachers' mobility, lack of a sense of belonging, the thinking of some of the teachers that complete the class is complete the task. Lack of communication and exchange with students, those have influence in teaching; Third, poor foundation of independent college students enrolled, lack of motivation to learn, varying cultural foundation of students, serious polarization, the same difficulty of the course does not meet the different needs of students, some teachers believe that it is not easy for independent school students to get a good score, even pay a high price, it is difficult to have a sense of accomplishment, all this factors lead to teaching enthusiasm and initiative affected of teachers.

\section{Less Effective Classroom Teaching}

Surveys show that independent college classroom teaching's students expressed their dissatisfaction with the quality of some teachers', the main reason for their dissatisfaction with the following aspects: the attitude on teaching, some teachers biased independent school students, college students believe that the independent students' foundation is poor, poor teaching Even putting in a lot of time and effort are not easy to produce good results, enthusiasm is not enough; in terms of curriculum, set up an independent college teaching content with this two identical, the selection of teaching content is not appropriate, there is no basis for an independent college teachers teaching objectives and student diversity Features implement individualized, but with the same lesson plans to teach students; in teaching methods, traditional teaching methods commonly used, did not carry out a lively classroom full of personality for independent college students, individual teachers lectures fashioned way, blunt, bar disarray, unfocused, And classroom's atmosphere is not active, there is a lack of interaction between teachers and students, classroom teaching is poor.

\section{Influencing Factors of Independent College Teaching Quality}

\section{Featureless of Independent Institute training objectives}

Independent college training objectives is to train the applied talents who is suitable for the development of local economic and social. Who have innovative and practical skills of application-oriented talents, and training objectives regular undergraduate school is different [5]. Therefore, according to their own independent colleges should strength of the school, student 
characteristics, in the curriculum fully reflect their strengths, reasonable arrangements for teaching content, highlighting their school characteristics, the real purpose for the society applied talents. However, the vast majority of independent colleges did not locate training objectives according to their school characteristics, and the convergence of the training objectives. There are also some independent colleges in personnel training does not adequately reflect their own advantages, not in accordance with the implementation of individualized student's personality, the second copy of the student's parent school personnel training program, leading students to develop without features.

\section{The Independent Institute professional setting unreasonable}

Professional setting unreasonable is an important factor affecting the quality of teaching of Independent Colleges. On the current situation, the Independent Institute professional setting unreasonable mainly in three aspects: First, set up an independent institute specializing in the same school with the parent, and copy of the same professional teaching content in personnel training, the curriculum ones, pretty difficult leading independent college's students arduous task, learning difficulty; the second it is lacks of talent who are required in society when you set up an independent institute specializing in research, professional setting out of touch with social needs, the curriculum seriously divorces from the local socio-economic development, students can't adapt to the social and economic development demand; Third independent college specialty categories too wide, nearly 10 major disciplines involved in the vast majority of professional. Owing to neglecting their own costs and teaching stuff blindly set top professional, leading a serious contradiction that independent college curriculum and teacher .

\section{Independent College Teaching Management System Is Not Perfect}

Currently, school autonomy, the right personnel, distribution rights and other independent colleges can not match its commitment to complete the task, most independent colleges is not yet fully formed their own teaching management, its teaching documents, regulations, generally on the basis of the original file slightly modified, it does not sound teaching management system is not suitable for the development of independent colleges. Main features: in the teaching process, teachers did not prepare teaching materials and lesson plans for the difference between independent college student basis, the characteristics of active thinking on teaching methods, the method does not consider the characteristics of flexible teaching independent college students; in classroom management, the independent Some teachers lack teaching experience Academy appointment, lecture tedious way, the students are late, leave early, class and do not listen carefully to ignore the phenomenon, did not fulfill the classroom teacher is the first person of the obligation; in the daily management, independent colleges emphasize only normal teaching, ignoring the curriculum, discipline and teaching staff, is not conducive to long-term development.

\section{Independent School faculty unstable}

Independent College faculty unstable, and its teaching mission and more from the parent school teachers, retired teachers and other university enterprises and institutions of professional and technical personnel as a part-time staff, fewer full-time teachers, teachers greater mobility. Moreover, independent college faculty on the age, knowledge and title structure is irrational, the quality of its teaching faculty is also problematic. Under normal circumstances, the school teacher from the mother as an independent college teaching, often at the same school and the same mother as independent college courses, in the independent college students to teach, often used to teach students of the two materials, lesson plans, teaching content and The teaching methods are also two identical; for external teachers, independent college in the recruitment of teachers is difficult to examine the quality of teaching, some external teachers not only lack of teaching experience and methods, but it is difficult to completely put their energies into teaching, not easy to manage.

\section{Independent School teaching quality supervision system is imperfect}

Special students and teachers to make the teaching quality instability of Independent Colleges monitoring difficult. First, a small independent college full-time teachers, the majority of part-time 
teachers are not entirely independent college, for part-time teachers, it is difficult to implement effective management and control; second, independent college school system more special, not fully formed their own teaching management, their job performance faculty and administrative staff assessment is difficult to quantify, can not play an effective monitoring system; third, the second copy of the teaching evaluation system, the independent college teaching quality monitoring does not apply, because the evaluation focused on the evaluation of the complete lesson plan and teaching schedule performance, ignoring the lesson plans, teaching schedule and independent college student adaptability, inadequate attention to the actual effect of teaching, teaching quality monitoring formality of Independent Colleges.

\section{Acknowledgement}

The author thanks funding support of agricultural university of Hebei teaching and research project(2015JM08),( 2012-A9), and funding support of Hebei higher education teaching reform project(2012GJJG028),( 2015 GJJG272).

\section{References}

[1] Ministry of Education of the People's Republic of China http://www.moe.edu.cn/publiciles/business/htmlfiles/moe/moe_271/201010/109693.html

[2] Ministry of Education of the People's Republic of China http://www.moe.gov.cn/publicfiles/business/htmlfiles/moe/s7567/201309/156899.html

[3] Zhang dianbing. Reflections on Teaching Quality Management in Colleges few basic questions[J].2006(3):58-60.

[4] Zhao jianzhong. Hotspot of global education development Reports from the 1990s UNESCO[M) 1999:421-42.

[5] Xie guangxu. Teaching quality independent research institute safeguards issues under diverse school system [D]. Tianjin University, 2011:32. 